\title{
EVALUASI PURNA HUNI SIRKULASI DAN FASILITAS TERMINAL KARTASURA
}

\author{
An Nuurrika Asmara Dina, Wisnu Setiawan \\ Program Studi Teknik Arsitektur, Fakultas Teknik, Universitas Muhammadiyah Surakarta \\ Jl. A. Yani Tromol Pos 1 Pabelan Kartasura Sukoharjo 57102 Telp 0271-717417 \\ E-mail: rika_kierby@yahoo.com, wisnu.setiawan@ums.ac.id
}

\begin{abstract}
ABSTRAK
Pelayanan kepada masyarakat dalam menggunakan kendaraan umum berupa bus, peningkatan kualitas dan penyediaan sarana transportasi yang memadai merupakan faktor yang perlu diperhatikan terutama masalah prasarana terminal. Penelitian ini dilakukan untuk melihat sejauh mana penerapan sirkulasi dan fasilitas terminal Kartasura sebagai terminal tipe B. Penelitian dilakukan dengan metode kualitatif (pengamatan langsung). Data yang telah diperoleh diklasifikasikan berdasarkan permasalahan, kemudian dibandingkan dengan kajian pustaka dan hasil wawancara. Hasil penelitian menunjukkan arah sirkulasi sudah sesuai dengan teori, namun $60 \%$ pengunjung belum merasa nyaman dan aman dengan sirkulasi yang diterapkan di terminal Kartasura. Fasilitas terminal Kartasura baru 50\% yang memenuhi syarat fasilitas terminal tipe B. Sejumlah $80 \%$ pengunjung mengungkapkan fasilitas di Terminal Kartasura kurang lengkap dan kurang terawat.
\end{abstract}

Kata Kunci: kualitas, sirkulasi, fasilitas

\section{LATAR BELAKANG}

Berdasarkan Undang-Undang No. 14 Tahun 1992 tentang Lalu Lintas dan Angkutan Jalan, terminal merupakan prasarana transportasi jalan untuk barang serta mengatur kedatangan dan pemberangkatan kendaraan umum yang merupakan satu wujud simpul jaringan transportasi.

Sukoharjo memiliki 2 terminal, yaitu Terminal Kartasura dan Terminal Sukoharjo. Terminal bus Kartasura awalnya berada di Jalan Ahmad Yani yang dekat dengan persimpangan jalan arah Solo - Jogja Semarang. namun karena luas terminal yang sudah tidak bisa menampung bus yang datang dan menjadikan kemacetan di Jalan Ahmad Yani akhirnya pemerintah memindahkan terminal bus Kartasura ke lahan yang lebih luas. Pada pertengahan bulan Juli 2003 terminal Kartasura berpindah di sekitar permukiman yang berada di Dukuh Argosuko, Wirogunan, Kartasura yang memiliki luas lahan 6,8 hektar.

Terminal Kartasura mulai beroperasi pada pertengahan tahun 2005, namun sampai sekarang kondisinya tidak membaik. Para pedagang di terminal mengeluh karena sepinya kondisi terminal akibat masih banyaknya bus yang tidak masuk ke dalam terminal. Bus antarkota antarprovinsi (AKAP) lebih memilih langsung melewati depan pasar Kartasura dan menurunkan penumpang di depan pasar Kartasura yang menyebabkan terminal menjadi sepi. Kepala Dishubinfokom Sukoharjo Bambang Sri Wahyono mengakui banyak fasilitas di terminal tersebut mengalami kerusakan, mulai dari kerusakan kecil hingga besar. Hal tersebut diyakini menyebabkan sopir bus dan calon penumpang tidak mau masuk ke dalam terminal (Solopos, 2011).

\section{PERUMUSAN MASALAH}

Peneliti melakukan wawancara awal dengan kepala Terminal Kartasura Sumaryadi (2014) menyatakan bahwa sepinya terminal Kartasura dikarenakan terminal tersebut sebagai terminal transit, yaitu terminal yang melayani aktifitas transit penumpang dari satu tujuan ke tujuan lain. Kendaraan umum hanya menurunkan dan menaikkan penumpang (wawancara, 2014). Beberapa pengunjung 
juga mengeluhkan minimnya papan informasi yang menunjukkan arah atau tempat kedatangan bus. Seperti yang diungkapkan Ibu Ning dari Klaten yang baru pertama kali datang ke terminal Kartasura bahwa beliau bingung harus naik bus apa dan menunggu bus di sebelah mana, karena tidak ada papan informasi/ ruang informasi yang memudahkan beliau (wawancara, 2014). Berbeda dengan pendapat Mas Hakim dari Jepara, menurut beliau tempat terminal Kartasura kurang strategis sehingga tidak banyak orang yang mau masuk ke dalam terminal. Beliau juga berpendapat bahwa pembangunan terminal kurang maksimal, terlihat banyak kios yang rusak, tidak ada kamar mandi terminal, tidak ada papan informasi dan semrawutnya sirkulasi antara bus, taxi dan kendaraan pribadi (wawancara, 2014).

Sedangkan menurut sopir bus malam "Bogor" bapak Agus, beliau mengeluhkan kebijakan pengelola terminal yang kurang tegas. Kendaraan pribadi yang bisa masuk dan parkir di sembarang tempat sangat mengganggu keamanan dan kenyamanan sirkulasi. Bapak Agus meminta agar disediakan jalur khusus untuk kendaraan pribadi atau parkir khusus dan kendaraan pribadi tidak diperbolehkan masuk ke dalam terminal (wawancara, 2014).

Uraian di atas menunjukkan indikasi bahwa Terminal Kartasura menghadapi beberapa permasalahan yang terkait dengan antara lain:

1. Sistem sirkulasi di Terminal Kartasura dalam mendukung kegiatan pelayanan parkir untuk bus dan angkutan umum serta sirkulasi penumpang.

2. Kesesuaian layanan fasilitas Terminal Kartasura dengan terminal Tipe B.

\section{TINJAUAN PUSTAKA}

\section{Pengertian Evaluasi Purna Huni}

Evaluasi Purna Huni atau dikenal sebagai Post Occupancy Evaluation (POE) adalah pengujian efektivitas sebuah lingkungan binaan bagi kebutuhan manusia, baik pengujian efektivitas bangunannnya sendiri maupun efektivitas programnya terhadap kebutuhan pengguna (Laurent, 2004).

Beberapa yang menjadi ciri evaluasi purna huni yaitu:

a. Evaluasi purna huni cenderung terfokus pada sebuah bangunan atau sebuah setting saja, seperti perkantoran, rumah dan sekolahan.

b. Kegiatan evaluasi cenderung lebih menguraikan situasi bangunan daripada memanipulasi setting.

c. Evaluasi dilakukan di lapangan bukan di laboratorium.

\section{Tinjauan Umum Terminal}

a. Terminal adalah titik di mana penumpang dan barang masuk dan keluar di dalam sistem dan merupakan komponen penting dalam sistem transportasi (Morlok, EK, 1991).

b. Beberapa ahli, seperti Edward K Morlok (1991) dan Suwardjoko P. Warpani (2002), menyimpulkan bahwa terminal mempunyai fungsi sebagai berikut:

1) Fungsi terminal bagi penumpang adalah untuk kenyamanan menunggu, kenyamanan perpindahan dari satu moda atau kendaraan ke moda atau kendaraan lain, tempat fasilitas-fasilitas informasi dan fasilitas parkir kendaraan pribadi.

2) Fungsi terminal bagi pemerintah adalah dari segi perencanaan dan manajemen lalu lintas untuk menata lalu lintas dan angkutan serta menghindari dari kemacetan, sumber pemungutan retribusi dan sebagai pengendali kendaraan umum.

3) Fungsi terminal bagi operator/ pengusaha adalah untuk mengatur operasi bus, menyediakan fasilitas istirahat dan informasi bagi awak bus dan sebagai fasilitas pangkalan.

4) Fungsi terminal bagi pengguna umum merupakan fasilitas suatu terminal seperti masjid, wc, loker tiket, pembelanjaan, dan sebagainya.

c. Tipe Terminal

Berdasarkan keputusan Menteri Perhubungan No 31/1995, terminal penumpang dibagi menjadi tiga tipe:

1) Terminal penumpang Tipe $A$ berfungsi melayani kendaraan umum atau angkutan antar kota antar propinsi dan/atau angkutan lintas batas negara, angkutan antar kota dalam propinsi, angkutan kota dan angkutan pedesaan. 
2) Terminal penumpang Tipe B berfungsi melayani kendaraan umum untuk angkutan antar kota dalam propinsi, angkutan kota dan/atau angkutan pedesaan.

3) Terminal penumpang Tipe $C$ berfungsi melayani kendaraan umum untuk angkutan pedesaan.

\section{d. Fasilitas Terminal}

Menurut Munawar (2005) fasilitas terminal dikelompokkan atas fasilitas utama dan fasilitas pendukung. Semakin besar suatu terminal semakin banyak fasilitas yang perlu disediakan.

1) Fasilitas Utama Terminal merupakan fasilitas yang mutlak dimiliki dalam terminal penumpang, meliputi antara lain: Jalur pemberangkatan kendaraan umum sebagai pelataran di dalam terminal penumpang yang disediakan bagi kendaraan umum untuk menaikkan penumpang.

a) Jalur kedatangan kendaraan umum merupakan pelataran di dalam terminal penumpang yang disediakan bagi kendaraan umum untuk menurunkan penumpang.

b) Tempat tunggu kendaraan umum adalah pelataran yang disediakan bagi kendaraan angkutan penumpang umum untuk beristirahat dan siap menuju jalur pemberangkatan.

c) Bangunan kantor terminal biasanya berada dalam wilayah terminal yang sering digabung dengan menara pengawas yang berfungsi sebagai tempat memantau pergerakan kendaraan dan penumpang.

d) Tempat tunggu penumpang atau pengantar perlu disediakan bagi orang yang akan melakukan perjalanan dengan angkutan umum atau orang yang mengantarnya.

e) Jalur lintasan disediakan bagi kendaraan angkutan penumpang umum yang akan langsung melakukan perjalanan setelah menurunkan atau menaikkan penumpang.

f) Loket penjualan karcis adalah ruangan yang digunakan oleh masing-masing penyelenggara angkutan untuk penjualan tiket perjalanan. g) Tempat istirahat sementara kendaraan disediakan bagi kendaraan untuk istirahat sementara dan dilakukan perawatan sebelum melanjutkan pemberangkatan.

h) Rambu-rambu dan papan informasi sekurang-kurangnya memuat petunjuk jurusan, tarif dan jadwal pemberangkatan.

2) Fasilitas Penunjang Terminal adalah fasilitas yang menunjang fasilitas utama sehingga dapat meningkatkan pelayanan terhadap penumpang, terdiri atas: kamar kecil / toilet, musholla, kios / kantin, ruang pengobatan, ruang informasi dan pengaduan, telepon umum, tempat penitipan barang, taman, dan lain-lain

e. Keamanan, Kenyamanan, Kelancaran, Kemudahan dan Kecepatan Sirkulasi.

Pada terminal untuk dapat mencapai fungsi dan tujuan mempunyai tuntutan yaitu keamanan, kenyamanan, kelancaran, kemudahan dan kecepatan (Adisasmita, 2011).

1) Keamanan sirkulasi

a) Menghindari crossing antara arus armada dengan manusia.

b) Penciptaan suasana yang dapat menghalangi tindak kejahatan terhadap penumpang.

c) Ada arus pergerakan kendaraan yang searah, kejelasan pembagian jalur arah yang berjalan dan tidak terjadi crossing.

2) Kenyamanan sirkulasi

a) Terminal merupakan bangunan umum yang membutuhkan keterbukaan dan keluasan pandangan.

b) Para pengguna terminal terhindar dari gangguan asap kendaraan, panas sinar matahari langsung, terlindung dari hujan serta kebisingan suara kendaraan.

c) Mempunyai ruang yang memenuhi syarat.

3) Kelancaran sirkulasi

a) Sirkulasi yang lancar tidak berdesakan dan tidak saling mengganggu. 
b) Adanya pemisah arus sirkulasi yang jelas.

c) Keleluasaan arus gerak bagi kendaraan dan penumpang.

d) Menghindari pola sirkulasi yang tidak terarah.

4) Kemudahan sirkulasi

a) Kemudahan bagi calon penumpang dalam memilih kendaraan yang sesuai dengan tujuan pelayanan yang dikehendaki.

b) Kemudahan pergerakan bus didalam terminal.

c) Kemudahan bagi penumpang untuk mencapai ruang-ruang lain yang diinginkan.

d) Pengelompokan kegiatan bus antar kota, dalam kota, antar propinsi dan angkutan agar mudah dalam pencapaian kendaraan umum

5) Kecepatan sirkulasi

a) Arus penumpang dan kendaraan dapat bergerak dengan cepat tanpa terganggu oleh kegiatan yang lain.

b) Penumpang dapat memperoleh kendaraan umum dengan tujuan yang diinginkan dengan cepat dari armada satu ke armada yang lain.

c) Keluar masuk kendaraan dan penumpang dari terminal dapat berjalan dengan cepat.

\section{Panduan pengamatan lapangan}

Kajian pustaka di atas menghasilkan serangkaian panduan pengumpulan data yang dapat diringkas dalam daftar objek pengamatan yang secara umum terbagi menjadi 2 bagian, yaitu sistem sirkulasi dan kelengkapan fasilitas di Terminal Kartasura.

\section{Sirkulasi}

Pengamatan dilakukan pada:

a. Jalur pemberangkatan kendaraan umum

b. Jalur kedatangan kendaraan umum

c. Jalur lintasan

d. Rambu-rambu

e. Pola Sirkulasi

\section{Fasilitas}

Pengamatan dilakukan pada:
a. Bangunan kantor terminal dan menara pengawas
b. Tempat tunggu penumpang dan pengantar
c. Loket penjualan karcis
d. Kamar mandi
e. Rambu-rambu dan papan informasi

\section{ANALISIS DAN HASIL}

Penelitian ini menggunakan 2 cara untuk mengumpulkan data. Penelitian dimulai dengan mengumpulkan data pertama melalui observasi lapangan. Selanjutnya, data kedua dilakukan melalui wawancara dengan beberapa responden. Sesuai panduan pencarian data yang ada di bagian kajian pustaka, observasi lapangan dilakukan dengan cara mengamati secara langsung sirkulasi, sistem parkir dan fasilitas Terminal Kartasura. Wawancara dilakukan untuk mendapatkan keterangan dari para responden mengenai keadaan Terminal Kartasura ini setelah pembangunan tahun 2005. Hasil lebih rinci dapat dilihat di bagian berikut ini.

\section{Pengamatan lapangan}

Pengamatan lapangan ditujukan kepada beberapa elemen yang ada di Terminal Kartasura seperti sirkulasi bus, sirkulasi kendaraan pribadi, sirkulasi pengunjung yang akan naik bus atau turun dari bus, sistem parkir yang digunakan untuk parkir bus dan kendaraan umum serta fasilitas. Hasil pengamatan menunjukkan beberapa hal sebagai berikut ini.

a. Terminal Kartasura menerapkan pola sirkulasi menyebar, yaitu masuk dan keluar pada pintu yang berbeda. Kemudian menyebar ke arah trayek yang akan mereka tuju (Gambar 1).

b. Kendaraan pribadi (sepeda motor dan mobil pribadi) bisa masuk dari arah mana saja, keluar dari arah mana saja, dan bahkan parkir di sembarang tempat (Gambar 2).

c. Pengunjung belum memiliki jalur sendiri untuk berjalan supaya terhindar dari cross sirculation dengan bus atau kendaraan pribadi.

d. Terminal Kartasura memiliki pola parkir bus yang berbeda-beda di beberapa tempat.

e. Hasil observasi lapangan menunjukkan kelengkapan fasilitas di Terminal Kartasura, baik yang dimiliki atau tidak dimiliki, sebagai terminal Tipe B (Tabel 1). 


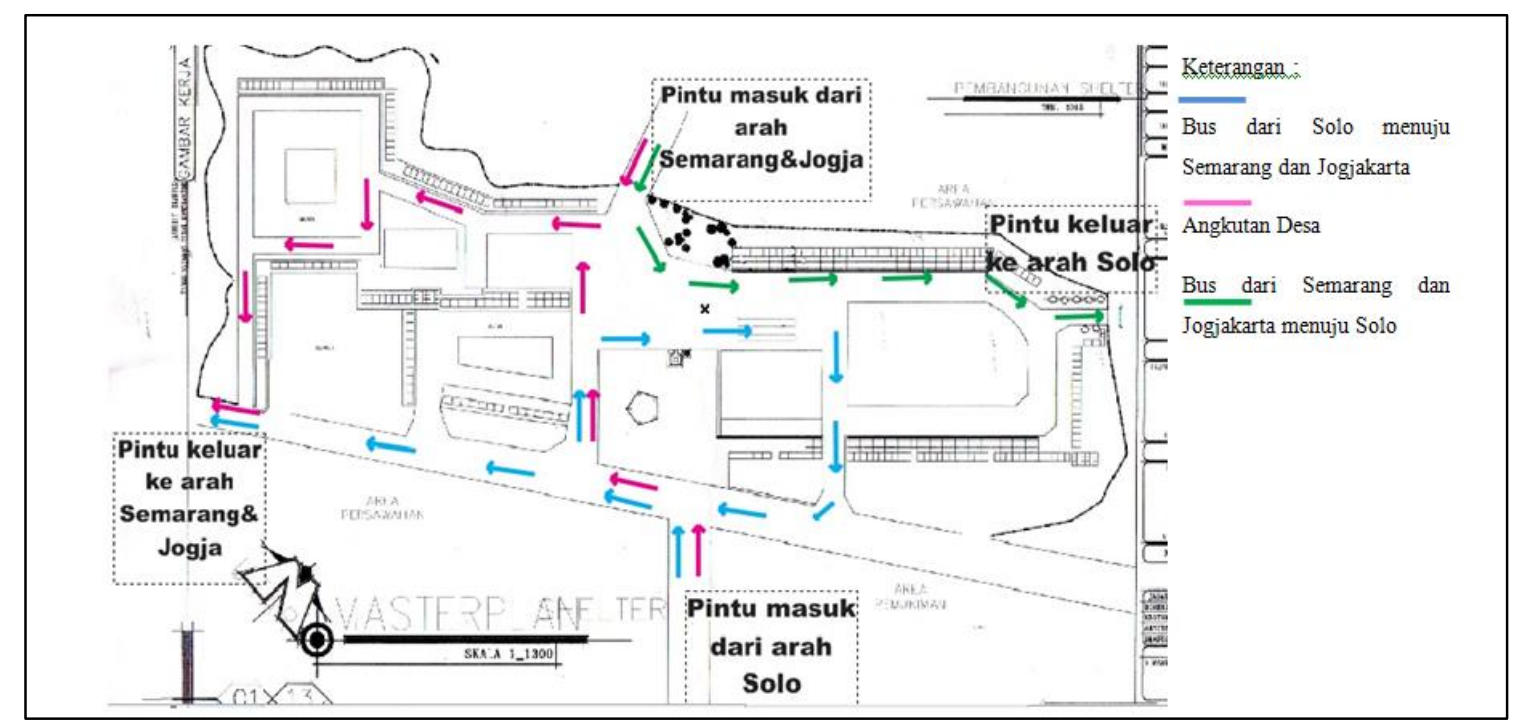

Gambar 1. Pola Sirkulasi

Sumber : Analisis penelti, 2013
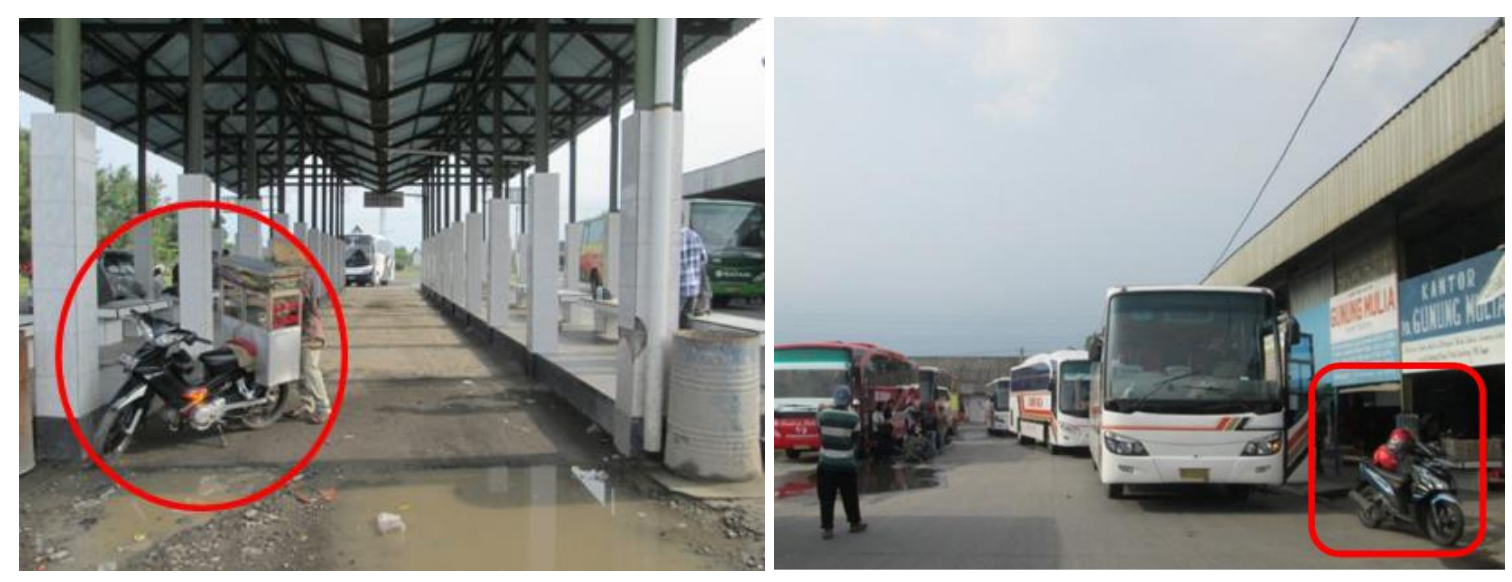

Gambar 2. Parkir tidak tertata

Sumber : Dokumen penulis, 2013

Tabel 1. Kesesuaian Fasilitas di Terminal Kartasura sebagai Terminal Tipe B

\begin{tabular}{|c|c|c|c|}
\hline No & Pembahasan & Standar & Lapangan \\
\hline \multicolumn{4}{|c|}{ Sirkulasi } \\
\hline 1. & Sirkulasi Bus & - Pola menyebar & $\sqrt{ }$ \\
\hline 2. & Sirkulasi kendaraan pribadi & $\begin{array}{l}\text { - Jalan masuk kendaraan harus dipisah } \\
\text { dengan jalur keluar kendaraan. } \\
\text { - Tempat perhentian harus diatur } \\
\text { penempatannya sesuai kebutuhan. } \\
\text { - Menghindari crossing antara arus armada } \\
\text { dengan manusia. }\end{array}$ & $\begin{array}{l}\sqrt{ } \\
\sqrt{ } \\
x\end{array}$ \\
\hline 3. & Sirkulasi pengunjung & $\begin{array}{l}\text { - Menghindari crossing antara arus armada } \\
\text { dengan manusia. } \\
\text { - Penciptaan suasana yang dapat } \\
\text { menghalangi tindak kejahatan terhadap } \\
\text { penumpang. }\end{array}$ & $\begin{array}{l}X \\
X\end{array}$ \\
\hline 4. & Sistem parkir bus & $\begin{array}{l}\text { - Parkir paralel } \\
\text { - } \quad \text { Parkir tegak lurus } \\
\text { - } \quad \text { Parkir gergaji lurus } \\
\text { - Parkir gergaji melingkar }\end{array}$ & $\begin{array}{l}1 \\
x \\
x \\
x\end{array}$ \\
\hline
\end{tabular}




\begin{tabular}{|c|c|c|c|}
\hline \multicolumn{4}{|c|}{ Fasilitas } \\
\hline 1. & Jalur pemberangkatan & - Harus dipisah dengan jalur kedatangan & $\sqrt{ }$ \\
\hline 2. & Jalur kedatangan & $\begin{array}{llll}\text { - } & \begin{array}{l}\text { Harus dipisah } \\
\text { pemberangkatan }\end{array} & \text { dengan jalur } \\
\end{array}$ & $\mathrm{x}$ \\
\hline 3. & Bangunan kantor & & \\
\hline 4. & Menara pengawas & Lebih tinggi dari bangunan kantor & $\mathrm{X}$ \\
\hline 5. & Ruang tunggu & $\begin{array}{l}\text { - Sejajar dengan arus kendaraan bus } \\
\text { - Tertutup oleh atap }\end{array}$ & $\begin{array}{l}\sqrt{ } \\
\sqrt{ }\end{array}$ \\
\hline 6. & Loket Penjualan karcis & - Dekat dengan pintu masuk terminal & $\mathrm{X}$ \\
\hline 7. & Kamar mandi & $\begin{array}{l}\text { - Di desain pada permukaan sama dengan } \\
\text { peron. } \\
\text { - Terletak dekat dengan ruang tunggu } \\
\text { penumpang. }\end{array}$ & $\begin{array}{l}X \\
\sqrt{ }\end{array}$ \\
\hline 8. & Rambu-rambu dan informasi & $\begin{array}{l}\text { Memuat petunjuk, tarif, dan jadwal } \\
\text { perjalanan } \\
\text { - Tulisan jelas dan bisa dipahami }\end{array}$ & $\begin{array}{l}X \\
\sqrt{ }\end{array}$ \\
\hline
\end{tabular}

Sumber : Analisis peneliti, 2012

Wawancara dengan pengguna terminal

a. Sirkulasi

Pihak pengelola terminal tidak mempunyai kebijakan tentang boleh tidaknya larangan kendaraan pribadi memasuki area terminal.

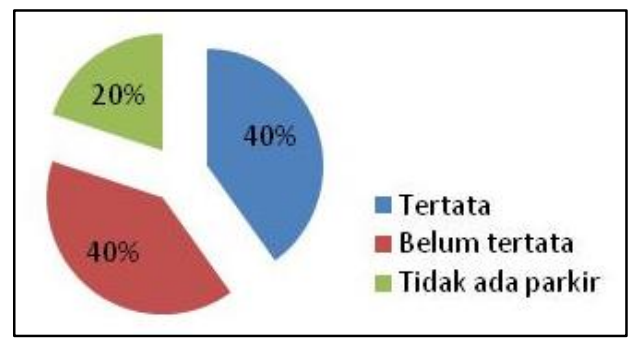

Gambar 3. Hasil survey tentang tata letak parkir bus dan sirkulasi di Terminal Kartasura Sumber: Analisis penulis, 2013

Hal ini menyebabkan 100\% responden yang diwawancarai merasa terganggu. Bahkan, mereka mengungkapkan pernah hampir tertabrak motor karena para pegendara yang ugal-ugalan (20\% responden). Berkaitan dengan area parkir bus dan tempat istirahat awak bus, $20 \%$ responden mengungkapkan bahwa mereka tidak pernah melihat bus yang parkir atau istirahat sejenak di tempat yang disediakan. Pendapat bahwa sistem parkir bus sudah tertata atau belum, pendapat responden berimbang antara $40 \%$ berbanding $40 \%$. Meskipun demikian, sebagian besar pengguna Terminal Kartasura, baik pengunjung, sopir, maupun pengelola, menyebutkan bahwa Terminal Kartasura masih belum tertata dengan baik (60\%), seperti yang diindikasikan oleh Gambar 3.

b. Fasilitas

Sebagian besar responden (80\%) mengungkapkan bahwa tidak ada parkir untuk kendaraan pribadi, dan $20 \%$ mengungkapkan bahwa tempat parkir pribadi yang di sediakan hanya untuk sepeda motor saja dan untuk mobil belum tersedia. $100 \%$ responden mengaku bahwa di Terminal Kartasura sudah memiliki tempat yang cukup untuk menaikkan tetapi belum memiliki tempat menurunkan penumpang yang nyaman. Menambahkan informasi tersebut, 70\% responden mengungkapkan bahwa jalur pemberangkatan di Terminal Kartasura sudah nyaman dan aman, namun $20 \%$ responden merasa kurang nyaman dan $10 \%$ mengaku tidak aman.

Berkaitan dengan rambu-rambu atau papan informasi jalur tujuan bagi pengunjung, sebanyak $10 \%$ responden mengatakan bahwa mereka tidak melihat rambu-rambu, $60 \%$ mengatakan bahwa rambu-rambu yang terpasang tidak cukup membantu para pengunjung. Hanya $30 \%$ responden merasa bahwa rambu-rambu yang terpasang di Terminal Kartasura sudah cukup jelas. Selain itu, 90\% responden berharap adanya penambahan papan informasi yang memuat petunjuk untuk penumpang seperti tarif, jadwal keberangkatan, petunjuk jalur menunggu, dan sebagainya. 
Secara umum, 60\% responden sudah merasa nyaman menunggu di sini dan sisanya $40 \%$ belum merasa nyaman. Ketidaknyamanan responden di akibatkan oleh polusi $(20 \%)$, kursi tunggu tanpa sandaran $(20 \%)$, tidak adanya petugas yang berjaga $(20 \%)$, serta desain atap yang kurang efektif untuk mengurangi panas di siang hari (10\%). Selain itu, semua responden mengakui bahwa bangunan terminal mengalami banyak kerusakan dan tidak terawat.

Hampir $80 \%$ pengguna terminal mengungkapkan bahwa fasilitas pendukung dan fasilitas utama yang ada di Terminal Kartasura masih belum lengkap (Gambar 4).

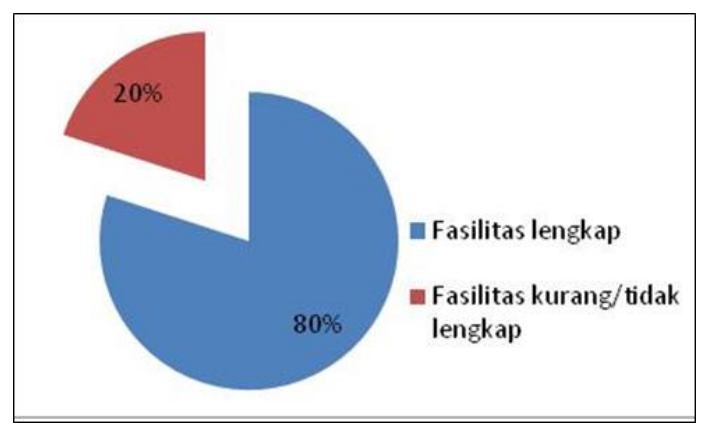

Gambar 4. Pendapat pengguna Terminal Kartasura tentang kelengkapan fasilitas Sumber: Analisis penulis, 2013

\section{KESIMPULAN DAN REKOMENDASI Kesimpulan}

a. Hasil penelitian menunjukkan bahwa sistem sirkulasi dan sistem parkir di Terminal Kartasura masih belum tertata. Sebagai contoh, sopir kurang mematuhi rambu-rambu yang telah terpasang, dan juga tidak ada jalur khusus untuk pengunjung. Tidak disiplinnya para sopir dan kurang tegasnya pengelola menyebabkan sirkulasi di Terminal Kartasura ini kurang aman.

b. Hasil penelitian menunjukkan bahwa Terminal Kartasura masih kurang sesuai dengan persyaratan sebagai terminal tipe $B$, terutama dilihat dari kelengkapan fasilitasnya. Masih ada beberapa fasilitas utama dan pendukung yang tidak terdapat di Terminal Kartasura.

\section{Rekomendasi}

Berdasarkan hasil penelitian dan kesimpulan, ada beberapa saran yang perlu disampaikan untuk meningkatkan kualitas pelayanan Terminal Kartasura.

a. Pemerintah daerah perlu lebih peduli dengan keadaan Terminal Kartasura saat ini dengan mewujudkan terminal yang berfungsi baik sebagai terminal tipe $B$ untuk melayani masyarakat.

b. Pengelola terminal perlu menerapkan kebijakan yang terkait dengan peraturan untuk menertibkan sopir, pengunjung dan pengelola. Selain itu, pengelola perlu lebih aktif terjun ke lapangan untuk mengontrol keadaan supaya tercipta suasana yang tertib dan aman.

c. Pengguna (pengunjung, sopir dan masyarakat) diharapkan ikut menjaga ketertiban dan keamanan Terminal Kartasura sehingga akan tumbuh kesadaran untuk mentaati dan menjalankan peraturan tanpa ada pengawasan.

\section{DAFTAR PUSTAKA}

Adisasmita, Sakti A. 2011. Perencanaan Pembangunan Trasnportasi. Graha IImu:Yogjakarta Keputusan Menteri Perhubungan No. 31 Tahun 1995

Laurent, Joyce M. 2004. Arsitektur dan Perilaku Manusia. Grasindo: Jakarta

Morlok, Edward K. 1991. Pengantar Teknik dan Perencanaan Transportasi. Erlangga : Jakarta

Munawar, Ahmad. 2005. Dasar-dasar Teknik Transportasi

Warpani, Suwardjoko P. 2002. Pengelola Lalu Lintas dan Angkutan Jalan. ITB 